\title{
Characterization of Colletotrichum acutatum Isolates Causing Anthracnose of Almond and Peach in California
}

\author{
J. E. Adaskaveg and R. J. Hartin
}

Department of Plant Pathology, University of California, Riverside 92521-0122.

Accepted for publication 25 June 1997.

\section{ABSTRACT}

Adaskaveg, J. E., and Hartin, R. J. 1997. Characterization of Colletotrichum acutatum isolates causing anthracnose of almond and peach in California. Phytopathology 87:979-987.

The causal organism responsible for the recent outbreak of almond and
peach anthracnose in California was identified and characterized as Coll-
etotrichum acutatum. Isolates of $C$. acutatum from almond were found to
be similar to California strawberry isolates and South Carolina peach and
apple isolates of $C$. acutatum based on conidial morphology, temperature
relationships, fungicide sensitivity, and polymerase chain reaction (PCR)
methods using DNA species-specific primers. On almond, blossoms and im-
mature or mature fruit were affected by the disease, causing direct losses
of crop. On peach, the disease was observed only on mature fruit. Patho-
genicity of almond and peach isolates of $C$. acutatum was demonstrated
on wound- and nonwound-inoculated almond or peach fruit by fulfilling
Koch's postulates. Conidial morphology of isolates was variable, depend-
ing on the medium or substrate used to culture the isolates. Isolates of $C$.
acutatum from strawberry, almond, and peach were grouped together based
on a similar response to temperature, with an optimal growth rate at $25^{\circ} \mathrm{C}$
(generally less than $10 \mathrm{~mm} /$ day), whereas isolates of $C$. gloeosporioides

The genus Colletotrichum Corda in Sturm. contains an extremely diverse number of fungi including both plant pathogens and saprophytes. Plant pathogenic species are important worldwide, causing pre- and postharvest losses of crops $(26,30)$. These fungi cause diseases commonly known as anthracnose of grasses, legumes, vegetables, small fruit, and perennial tree crops (30). The disease can occur on leaves, stems, and fruit of host plants. Typical symptoms include sunken subcircular or angular lesions that produce erumpent, mucilaginous, pink spore masses under conducive environments. In California, three species have been reported on strawberry: C. gloeosporioides (Penz.) Penz. \& Sacc. in Penz., C. acutatum J.H. Simmonds, and C. fragariae $(12,14)$; whereas only $C$. gloeosporioides has been reported from almond (19). One of the most common species of the genus is $C$. gloeosporioides (teleomorph Glomerella cingulata). This species causes anthracnose on a wide range of plants including temperate and tropical fruits $(8,18)$ and has been reported from almond (19) and citrus (22). C. fragariae has only been reported on strawberry in California $(12,14)$, but $C$. acutatum occurs on a wide variety of hosts (7).

Almond and peach anthracnose have rarely been reported in California $(19,27)$. The disease was first reported on almonds from Napa and Alameda counties in 1915 and was considered to be caused by Gloeosporium amygdalinum (5). The disease on almonds also occurs in Italy (5), France (13), Israel (20), and South Africa

Corresponding author: J. E. Adaskaveg; E-mail address: jim.adaskaveg@ucr.edu

Publication no. P-1997-0725-01R

(C) 1997 The American Phytopathological Society from citrus and papaya had an optimal growth rate at $30^{\circ} \mathrm{C}$ (generally greater than $10 \mathrm{~mm} /$ day). In fungicide disk assays, isolates of C. acutatum from strawberry, peach, and apple, as well as almond and peach isolates from California, were less sensitive to benomyl at 300,600 , or $1,200 \mu \mathrm{g} / \mathrm{ml}$. In contrast, C. gloeosporioides isolates from citrus and papaya were very sensitive to benomyl at all concentrations evaluated. All isolates of both species were sensitive to captan $(300,600$, or $1,200 \mu \mathrm{g} / \mathrm{ml})$. Oligonucleotide primers were synthesized for C. acutatum, C. fragariae, or $C$. gloeosporioides using published DNA sequences from the internal transcribed spacer 1 region of ribosomal DNA. Thirty-two Colletotrichum isolates from almond fruit produced DNA products with a $C$. $a c u$ tatum primer (CaInt-2) that matched products and approximate molecular weight of known $C$. acutatum isolates. No PCR products were produced with primers for $C$. gloeosporioides or $C$. fragariae. Isolates from citrus and papaya produced DNA products only with primers from C. gloeosporioides or $C$. fragariae. Thus, worldwide, anthracnose of almonds may be caused by either $C$. gloeosporioides, as previously reported, or by $C$. acutatum, as indicated in this study.

Additional keywords: fruit and nut tree diseases, Prunus dulcis, P. persica.

(6). von Arx (29) considered G. amygdalinum a synonym of $C$. gloeosporioides and identified the pathogen of almond anthracnose as the latter fungus (20). In California, the disease was observed more recently in orchards in northern California in the mid1980 s by cooperative extension personnel and was reported to the Almond Board of California by J. E. Adaskaveg and J. M. Ogawa after several outbreaks on almond in central and northern California from 1992 to $1996(1,2)$. Peach and nectarine anthracnose is commonly observed in the southeastern United States, but is uncommon in California. In 1990, the disease was reported as a postharvest pathogen of peaches and nectarines in Fresno County (19).

Species of Colletotrichum have been identified almost exclusively based on morphological and cultural characteristics. Characters such as conidial morphology, presence or absence of setae, presence or absence of the teleomorph, colony color, production of pigments, and growth rate have been used to differentiate species. $C$. gloeosporioides has cylindrical conidia with rounded ends, develops setae and the teleomorph state, and the dark gray colonies have an average growth rate of 13 to $14 \mathrm{~mm} /$ day $(14,18)$. Isolates of $C$. fragariae are similar to $C$. gloeosporioides, but lack the teleomorph and produce abundant conidia. C. acutatum forms fusiform conidia, rarely produces setae, lacks a teleomorph, and the light gray colonies have an average growth rate of 8 to $9 \mathrm{~mm} /$ day (7, 14). Identification of these species, however, is difficult, because of the extreme variation in morphology accepted for C. gloeosporioides (26) and other species of the genus. Isolates of these species have overlapping ranges of conidial morphology and show wide variation in colony characteristics. Attempts to distinguish strawberry isolates of three Colletotrichum species based on the foregoing characteristics have been limited (26). 
Recently, Mills et al. (17) determined the nucleotide sequence of the internal transcribed spacer (ITS) 1 region of several Colletotrichum species. Based on this information, primers were developed and used with the conserved primer ITS 4 (31). These primers were shown to be effective for identification of $C$. coccodes, with no DNA products produced with other closely related species. The primers also were useful for identification of C. gloeosporioides, C. fragariae, and C. kahawe. The primer developed and tested for $C$. acutatum, however, was not effective in distinguishing this species from $C$. gloeosporioides or $C$. fragariae isolates from strawberry. Other techniques such as arbitrarily primed polymerase chain reaction (PCR) also have been used to differentiate Colletotrichum species $(10,11,15,16)$.

TABLE 1. Isolates of Colletotrichum species, isolation hosts, and source location of collections

\begin{tabular}{|c|c|c|}
\hline Isolate $^{\mathrm{x}}$ & Host $^{y}$ & Source location ${ }^{z}$ \\
\hline EEB 99 & Strawberry & California \\
\hline EEB 100 & Strawberry & Yolo, CA \\
\hline EEB 101 & Strawberry & Yolo, CA \\
\hline EEB 1995 & Strawberry & California \\
\hline EEB 1997 & Strawberry & California \\
\hline JEA 92-5 & Almond & Merced, CA \\
\hline JEA 92-6 & Almond & Merced, CA \\
\hline JEA 92-8 & Almond & Merced, CA \\
\hline JEA 92-16 & Almond & Butte, CA \\
\hline JEA 92-18 & Almond & Butte, CA \\
\hline JEA 95-1 & Almond & Butte, CA \\
\hline JEA 95-2 & Almond & Butte, CA \\
\hline JEA 95-3 & Almond & Butte, CA \\
\hline JEA 95-4 & Almond & Butte, CA \\
\hline JEA 96-1 & Almond & Merced, CA \\
\hline JEA 96-2 & Almond & Merced, CA \\
\hline JEA 96-7 & Almond & Merced, CA \\
\hline JEA 96-8 & Almond & Merced, CA \\
\hline JEA 96-14 & Almond & Merced, CA \\
\hline JEA 96-15 & Almond & Merced, CA \\
\hline BLT 95-3 & Almond & Stanislaus, CA \\
\hline BLT 95-4 & Almond & Stanislaus, CA \\
\hline BLT 95-5 & Almond & Stanislaus, CA \\
\hline BLT 95-6 & Almond & Butte, CA \\
\hline BLT 95-7 & Almond & Butte, CA \\
\hline BLT 95-8 & Almond & Butte, CA \\
\hline BLT 95-9 & Almond & Butte, CA \\
\hline BLT 95-10 & Almond & Butte, CA \\
\hline BLT 95-11 & Almond & Butte, CA \\
\hline BLT 95-17 & Almond & Stanislaus, CA \\
\hline BLT 95-18 & Almond & Stanislaus, CA \\
\hline BLT 95-19 & Almond & Stanislaus, CA \\
\hline ВТМ 95-4 & Peach & Yuba, CA \\
\hline BTM 95-5 & Peach & Yuba, CA \\
\hline BTM 95-6 & Peach & Yuba, CA \\
\hline BTM 95-7 & Peach & Yuba, CA \\
\hline ВТМ 95-8 & Peach & Yuba, CA \\
\hline EIZ 719 & Peach & South Carolina \\
\hline EIZ 720 & Peach & South Carolina \\
\hline EIZ 721 & Peach & South Carolina \\
\hline EIZ 722 & Peach & South Carolina \\
\hline EIZ 723 & Apple & South Carolina \\
\hline JMO 94-22 & Citrus & Yolo, CA \\
\hline RJH 96-1 & Papaya & Hawaii \\
\hline RJH 96-2 & Papaya & Hawaii \\
\hline RJH 96-3 & Papaya & Hawaii \\
\hline RJH 96-4 & Papaya & Hawaii \\
\hline RJH 96-6 & Papaya & Hawaii \\
\hline RJH 96-7 & Papaya & Hawaii \\
\hline RJH 96-9 & Papaya & Hawaii \\
\hline RJH 96-10 & Papaya & Hawaii \\
\hline
\end{tabular}

${ }^{\mathrm{x}}$ Identification codes refer to isolate numbers in the culture collection of the following researchers: EEB, E. E. Butler; JEA, J. E. Adaskaveg; BLT, B. L. Teviotdale; BTM, B. T. Manji; RJH, R. J. Hartin; and EIZ, E. I. Zehr.

y Isolates from citrus and papaya are $C$. gloeosporioides, all others are $C$. acutatum.

z Source location in the United States. For almond isolates within California, county of collection is also provided.
Because of the recent outbreak and the sporadic occurrence of almond anthracnose in the history of almond production in California and the potential to resolve Colletotrichum species using classical and newly developed molecular techniques, the hypothesis tested was that a species of Colletotrichum other than the previously reported pathogen of almond anthracnose, C. gloeosporioides, was responsible for the recent disease outbreaks. Thus, the objectives were to collect isolates of Colletotrichum species from almond and peaches in California; compare these isolates with reference isolates of $C$. acutatum and C. gloeosporioides; characterize cultures of Colletotrichum isolates with regard to pathogenicity, conidial morphology, and sensitivity to selected fungicides; and evaluate primers based on published DNA sequences of a variable region in the ITS 1 of $C$. gloeosporioides, C. acutatum, and C. fragariae for the identification of the Colletotrichum isolates collected.

\section{MATERIALS AND METHODS}

Collection of isolates. Thirty-two isolates of Colletotrichum were obtained from diseased fruit of almonds and peaches, singlespore-cultured, grown on Difco potato dextrose agar (PDA; Difco Laboratories, Detroit) at $25^{\circ} \mathrm{C}$, and evaluated after 7 to 10 days for macroscopic cultural characteristics. Isolates, collection codes, original hosts, and source locations are listed in Table 1. These collections were compared with stock collections of five strawberry isolates from California and four peach isolates and one apple isolate from South Carolina designated as C. acutatum. Additionally, one citrus isolate from California and eight papaya isolates from Hawaii designated as $C$. gloeosporioides were also compared (Table 1). Cultures were maintained on PDA slants at $4^{\circ} \mathrm{C}$.

Conidial morphology and temperature relationships. For morphological observations and measurements of conidia, representative isolates from each host were grown on PDA, pea straw agar (PSA), or almond fruit. Pea straw was sterilized using propylene oxide for $48 \mathrm{~h}$ (28), and several leaf and stem pieces were added to molten water agar that was poured into petri dishes (approximately $50 \mathrm{mg} / 15 \mathrm{ml}$ ). Plates of PDA and PSA were simultaneously inoculated using $100 \mu$ of a conidial suspension $(1 \times$ $10^{5}$ conidia/ml) of each isolate, and the suspensions were spread over the surface of the medium using a glass rod. Almond fruit were surface-disinfested, wounded, placed in plastic containers, and inoculated with $20 \mu \mathrm{l}$ of a conidial suspension $\left(1 \times 10^{5}\right.$ conidia $\left./ \mathrm{ml}\right)$. Inoculated plates and fruit were incubated under continuous fluorescent light for 3 to 4 days at $25^{\circ} \mathrm{C}$. To determine morphology, conidia were mounted in water, observed using differential interference contrast microscopy, and photographed using a Sony DKC5000 digital camera (Sony Corp. of America, Montvale, NJ) mounted on a Zeiss Axioskop compound microscope (Carl Zeiss, Inc., Thornwood, NY). One hundred conidia of each isolate were measured in length and width (at the middle of the spore), and the experiment was conducted twice. The factorial experiment for fungal isolate and medium or substrate was evaluated using an analysis of variance and means were separated using Duncan's multiple range test provided in the statistical algorithms of SAS version 6.04 (SAS Institute, Cary, NC).

Colony diameter of selected isolates was recorded daily for 1 week for cultures grown on PDA in the dark at 10, 15, 20, 25, 30, 35 , or $40^{\circ} \mathrm{C}$. Petri plates containing PDA were inoculated in the center of each plate with a 6-mm-diameter plug obtained from the margin of a 5- to 7-day-old culture also grown on PDA. Three replications of each isolate at each temperature were evaluated, and the experiment was repeated once. Growth rate was calculated as the 7-day average of mean daily growth rate (millimeters per day) for each culture and temperature.

Fungicide sensitivity assays. To determine the sensitivity of isolates to captan and benomyl, PDA petri plates were simultaneously inoculated with a conidial suspension of each isolate as described above. Filter paper disks (12 $\mathrm{mm}$ in diameter), previously satu- 
rated with $100 \mu \mathrm{l}$ of $0,300,600$, or $1,200 \mu \mathrm{g} / \mathrm{ml}$ of either benomyl or captan and air-dried, were placed on the surface of inoculated PDA plates. The plates were incubated for 3 days at $25^{\circ} \mathrm{C}$, the radius of the inhibition zone was recorded for each fungicide concentration evaluated, and plates were photographed using a Sony DKC-5000 digital camera (Sony Corp. of America). Three replications of each isolate for each fungicide concentration were evalu- ated, and the experiment was repeated once. The factorial experiment was evaluated using general linear model procedures and means were separated using Tukey's studentized range test provided in the statistical algorithms of SAS version 6.04 (SAS Institute).

Pathogenicity studies. Approximately 6 to 10 weeks after bloom, almond fruit, cultivar Drake, were used in pathogenicity studies with almond isolates JEA 92-6 or JEA 92-16. In laboratory studies,

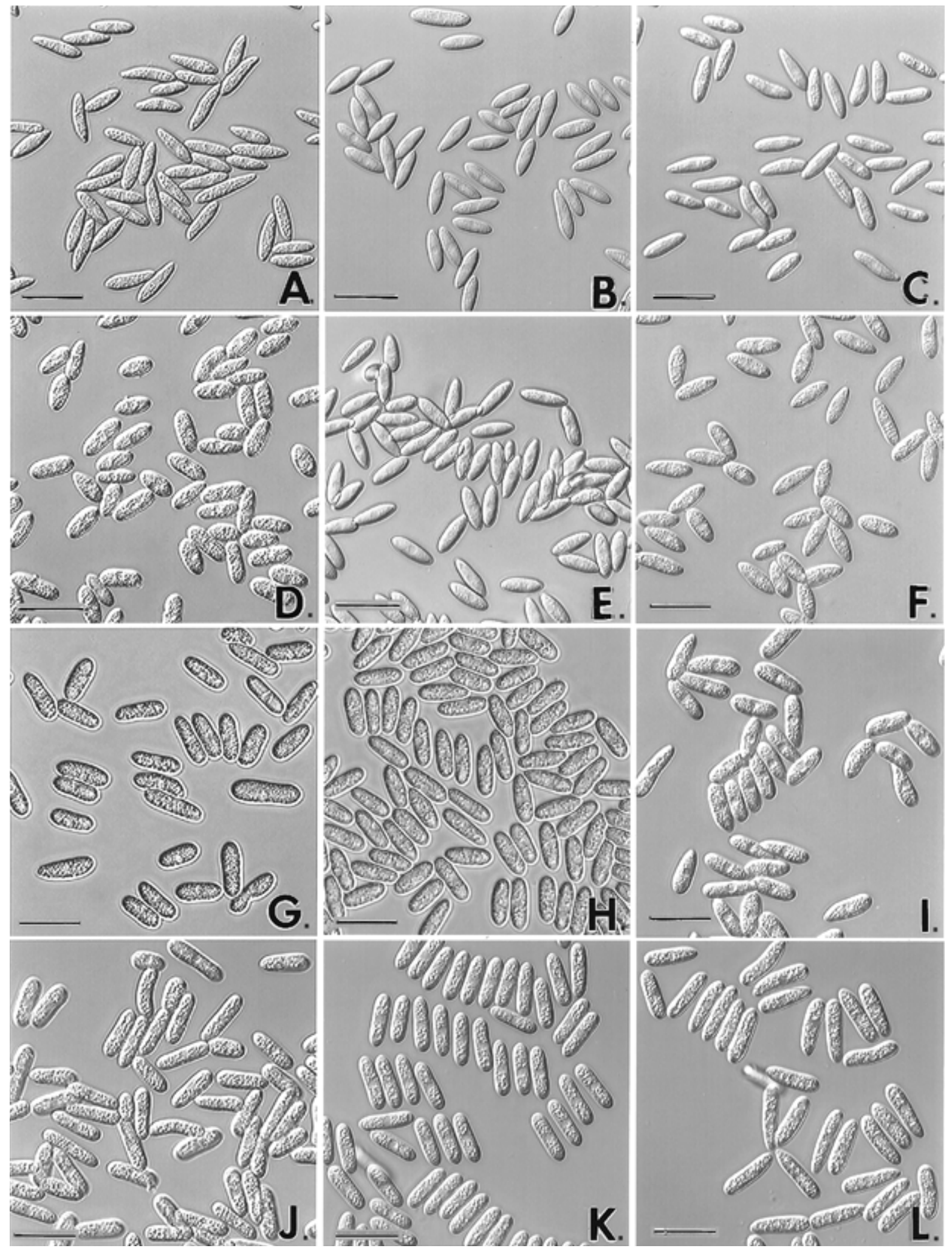

Fig. 1. Conidial morphology of Colletotrichum isolates from A, B, and C, strawberry (isolate EEB 101); D, E, and F, almond (isolate JEA 92-8); G, H, and I, citrus (isolate JMO 94-22); and $\mathbf{J}, \mathbf{K}$, and $\mathbf{L}$, papaya (isolate RJH 96-9) grown on A, D, G, and J, potato dextrose agar (column one); B, E, H, and K, pea straw agar (column two); and $\mathbf{C}, \mathbf{F}, \mathbf{I}$, and $\mathbf{L}$, almond fruit (column three). Bars $=20 \mu \mathrm{m}$. 
detached fruit were surface-disinfested for $2 \mathrm{~min}$ in a $0.84 \%$ (vol/ vol) solution of $\mathrm{NaOCl}$ (household bleach), rinsed in sterile distilled water, and then air-dried at $25^{\circ} \mathrm{C}$. Fruit were either nonwounded and spray-inoculated to run-off or wounded $(1 \times 1 \times 0.5 \mathrm{~mm})$ using a sterile glass rod and inoculated with $20 \mu \mathrm{l}$ of a conidial suspension of each fungus $(30,000 \mathrm{conidia} / \mathrm{ml})$. Conidia were obtained from 5- to 7-day-old cultures grown on PDA. Fruit were then placed on metal racks in plastic containers $(30 \times 20 \times 10 \mathrm{~cm})$ containing $100 \mathrm{ml}$ of water (fruit were not in contact with the water) and incubated for 5 to 7 days at $25^{\circ} \mathrm{C}$ and $>95 \%$ relative humidity. In field studies, nonsurface-disinfested, attached fruit on terminal branches were inoculated as previously described for both inoculation techniques. The branch was then placed in a plastic bag containing a wet paper towel, covered with a brown paper bag, and the closed bags were tied to the almond branch. Bags were removed after $18 \mathrm{~h}$ of wetness, and fruit were evaluated for disease incidence after 10 to 12 days. Tissue from diseased fruit was excised, surface-disinfested as described above, and placed on PDA. Sterile water was used in check treatments. For laboratory studies, four replications of five fruit were used for each inoculation treatment, and the experiment was conducted twice. For field studies, four single-tree replications of 15 to 20 fruit per replication were used for each inoculation treatment, and the experiment was done twice. Data were analyzed using analysis of variance and Duncan's multiple range test for mean separation procedures using the statistical algorithms of SAS version 6.04 (SAS Institute).

Additionally, almond fruit, cultivar Drake, or peach fruit, cultivars Ross or Elegant Lady, were wounded, placed in plastic containers, and inoculated using a conidial suspension as described previously with either of two almond isolates (JEA 92-6 and 92-8), one peach (BTM 95-4), one strawberry (EEB 99), one citrus (JMO 94-22), or one papaya isolate (RJH 96-4). Disease incidence was determined after fruit were incubated for 5 to 7 days at $25^{\circ} \mathrm{C}$ and $>95 \%$ relative humidity. Three replications of three fruit were used, and the experiment was done twice. Data were analyzed using analysis of variance and Duncan's multiple range test for mean separation procedures using the statistical algorithms of SAS version 6.04 (SAS Institute).

Extraction of fungal DNA. Total DNA was extracted from mycelium obtained from cultures grown on PDA for 2 to 3 days at $24^{\circ} \mathrm{C}$. Aerial mycelium was removed from a $2-\mathrm{cm}^{2}$ area of each culture using a sterile transfer needle and placed in a sterile $1.5-\mathrm{ml}$ microcentrifuge tube containing $300 \mu \mathrm{l}$ of extraction buffer $(0.2 \mathrm{M}$ Tris- $\mathrm{HCl}, 0.25 \mathrm{M} \mathrm{NaCl}, 25 \mathrm{mM}$ EDTA, and $2 \%$ sodium dodecyl sulfate, $\mathrm{pH}$ 8.5). Tubes were uncapped and placed in a boiling water bath for $5 \mathrm{~min}$ and then cooled to $25^{\circ} \mathrm{C} ; 200 \mu \mathrm{l}$ of phenol that was equilibrated with extraction buffer (vol/vol), and $200 \mu \mathrm{l}$ of chloroform were added. The tubes were vortexed for $4 \mathrm{~min}$, and

TABLE 2. Comparison of length-width ratios of conidia from selected isolates of Colletotrichum spp. originally obtained from anthracnose lesions on fruit and grown on potato dextrose agar (PDA), pea straw agar (PSA), or inoculated almond fruit ${ }^{\mathrm{y}}$

\begin{tabular}{llccc}
\hline & & \multicolumn{3}{c}{ Length-width ratio $^{\mathrm{z}}$} \\
\cline { 3 - 5 } Isolate $^{\mathrm{y}}$ & Original host & PDA & PSA & Fruit \\
\hline EEB 99 & Strawberry & $3.8 \pm 0.5 \mathrm{a}$ & $3.6 \pm 0.4 \mathrm{~b}$ & $3.5 \pm 0.5 \mathrm{~b}$ \\
JEA 92-8 & Almond & $2.6 \pm 0.4 \mathrm{f}$ & $3.2 \pm 0.3 \mathrm{c}$ & $3.1 \pm 0.4 \mathrm{~d}$ \\
JEA 92-18 & Almond & $3.1 \pm 0.4 \mathrm{~d}$ & $3.5 \pm 0.4 \mathrm{~b}$ & $3.0 \pm 0.4 \mathrm{~d}$ \\
BTM 95-4 & Peach & $2.9 \pm 0.5 \mathrm{e}$ & $3.2 \pm 0.3 \mathrm{c}$ & $3.3 \pm 0.5 \mathrm{c}$ \\
JMO 94-22 & Citrus & $3.28 \pm 0.5 \mathrm{c}$ & $2.9 \pm 0.3 \mathrm{~d}$ & $3.0 \pm 0.5 \mathrm{~d}$ \\
RJH 96-4 & Papaya & $3.54 \pm 0.7 \mathrm{~b}$ & $3.9 \pm 0.3 \mathrm{a}$ & $4.3 \pm 0.4 \mathrm{a}$ \\
\hline
\end{tabular}

y Cultures of each isolate were inoculated on PDA or PSA and incubated for 3 days at $25^{\circ} \mathrm{C}$; on almond fruit, cultures were inoculated and incubated for 5 to 7 days at $25^{\circ} \mathrm{C}$.

${ }^{\mathrm{z}}$ Ratios are based on the average of 100 length-width $(\mu \mathrm{m})$ ratios of 100 conidia per isolate for each medium or substrate. Values followed by the same letter were not significantly different based on Duncan's multiple range test $(P<0.05)$. then centrifuged at $13,844 \times g(12,000 \mathrm{rpm})$ for $5 \mathrm{~min}$. The supernatant was pipetted to a new sterile $1.5-\mathrm{ml}$ tube and $200 \mu \mathrm{l}$ of chloroform was added; the mixture was vortexed for $30 \mathrm{~s}$ and then centrifuged at $13,844 \times g$ for $15 \mathrm{~min}$. The supernatant was again transferred to a new $1.5-\mathrm{ml}$ tube and $200 \mu \mathrm{l}$ of isopropanol was added; the capped tube was inverted several times to adequately mix and precipitate DNA and then centrifuged at $13,844 \times g$ for $15 \mathrm{~min}$. The supernatant was discarded, and the nucleic acid pellet was washed in $400 \mu$ of $70 \%$ ethanol and centrifuged at 13,844 $\times$ $g$ for $5 \mathrm{~min}$. Again the supernatant was discarded, and the nucleic acid pellet was air-dried for 10 to $15 \mathrm{~min}$, resuspended in $50 \mu \mathrm{l}$ of low-TE buffer (10 mM Tris- $\mathrm{HCl}$ and $0.1 \mathrm{mM}$ EDTA, $\mathrm{pH} 8.5$ ), and gently agitated to dissolve the DNA. DNA was treated with Ribonuclease A (R4875; Sigma Chemical Co., St. Louis) for a final concentration of $10 \mu \mathrm{g}$ of $\mathrm{RNase} / \mathrm{ml}$ for $1 \mathrm{~h}$ at $37^{\circ} \mathrm{C}$.

PCR analysis. Species-specific target primers were synthesized for C. gloeosporioides (CgInt) 5'-GGCCTCCCGCCTCCGGGCGG-3', for $C$. acutatum (CaInt-1) 5'-GGCGCCGGCCCCCACCACGGGGA$3^{\prime}$ and (CaInt-2) 5'-GGCGCCGGCCCCGTCACGGGGG-3', and for C. fragariae (CfInt) 5'-GGCCTCCCGCCCCCCCGGCGG-3'
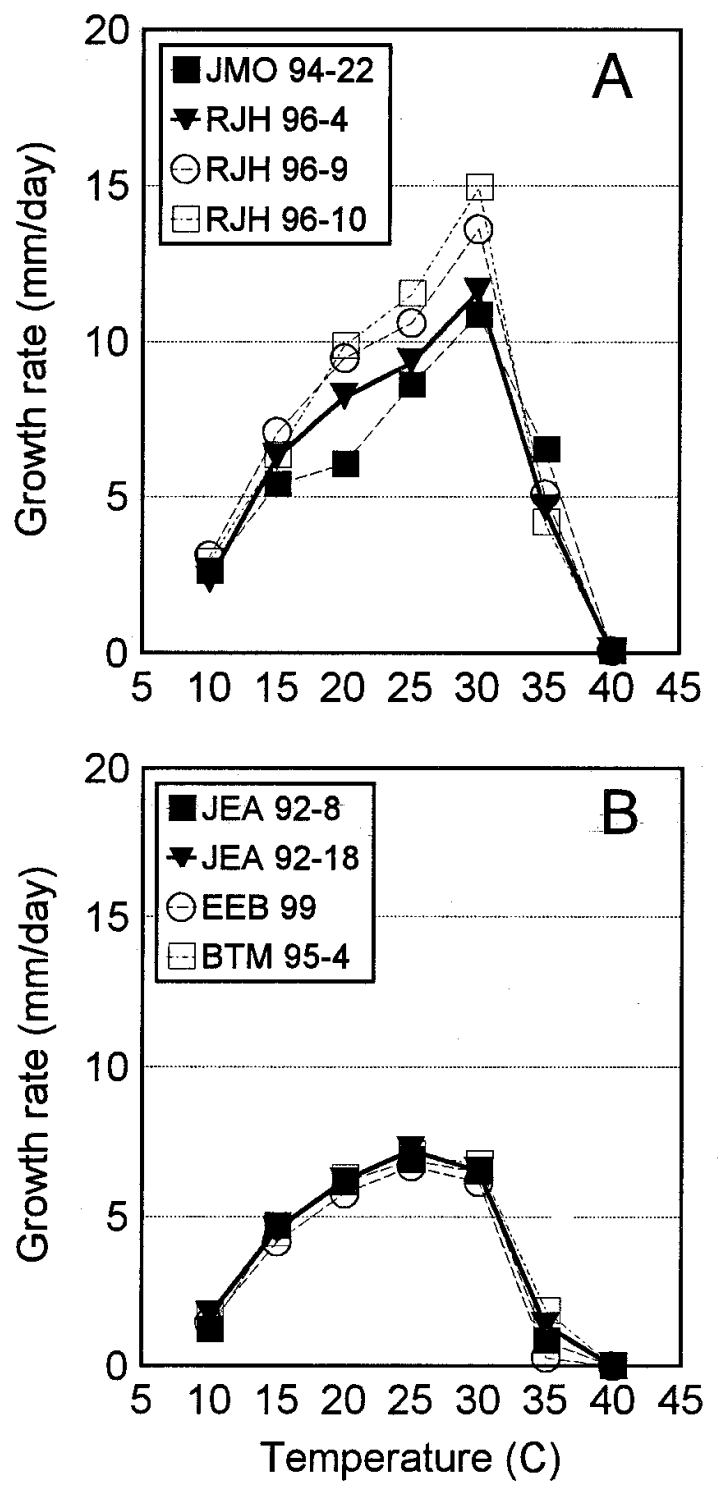

Fig. 2. Temperature relationships of Colletotrichum isolates from $\mathbf{A}$, citrus (isolate JMO 94-22) and papaya (isolates RJH 96-4, 96-9, and 96-10); and B, strawberry (isolate EEB 99), almond (isolates JEA 92-8 and 92-18), and peach (isolate BTM 95-4). Growth rate was calculated over a 5-day period at each temperature. Values are the average of three replications per isolate and temperature. The experiment was conducted twice. 
from ITS 1 of the ribosomal DNA (rDNA) gene based on published DNA sequences (17). Target primers were used with the conserved primer ITS 4 (31). Primers were synthesized by Oligos Etc., Inc. (Wilsonville, OR).

PCR amplification was performed in a $25-\mu$ l reaction mixture containing $1.5 \mu \mathrm{l}$ of DNA extract (approximately 1 to $5 \mathrm{ng}$ of DNA) in low-TE buffer; $4 \mu \mathrm{l}$ of $200 \mu \mathrm{M}$ each of dATP, dCTP, dGTP, and dTTP; $2.5 \mu \mathrm{l}$ of $10 \times \mathrm{Taq}$ reaction buffer $(500 \mathrm{mM} \mathrm{KCl}, 100 \mathrm{mM}$ Tris-HCl [pH 9.0], and 1\% Triton X-100); $0.5 \mu \mathrm{l}$ of $100 \mu \mathrm{M}$ $\mathrm{MgCl}_{2} ; 1.0 \mu \mathrm{l}$ of $1 \mu \mathrm{M}$ target primer; $1 \mu \mathrm{l}$ of $1 \mu \mathrm{M}$ ITS 4 primer; $0.13 \mu \mathrm{l}$ of Taq DNA polymerase (0.65 units); and $14.37 \mu \mathrm{l}$ of sterile water. A thermocycler (model PTA-100; MJ Research Inc., Watertown, MA) was programmed for 35 cycles of denaturation $\left(94^{\circ} \mathrm{C}\right.$ for $\left.1 \mathrm{~min}\right)$, annealing $\left(59^{\circ} \mathrm{C}\right.$ for $\left.2 \mathrm{~min}\right)$, and DNA extension $\left(72^{\circ} \mathrm{C}\right.$ for $\left.2 \mathrm{~min}\right)$. Following amplification, PCR products and $\lambda$ Hind III marker were separated using electrophoresis in 1\% (wt/ vol) agarose gels in Tris-HCl buffer, stained in ethidium bromide $(0.4 \mu \mathrm{g} / \mathrm{ml})$, viewed, and photographed using Polaroid black and white film (Polaroid Corp., Cambridge, MA) on a UV transilluminator.

\section{RESULTS}

Cultural and conidial morphology. Among the peach and almond isolates collected from California, aerial mycelium was grayish to pink with bright orange spore masses produced outward from the center of the culture, whereas the reverse or underside

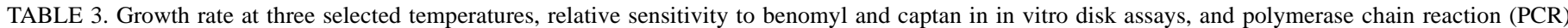
amplification products using CaInt-2 or CgInt primers for isolates of Colletotrichum acutatum and C. gloeosporioides evaluated

\begin{tabular}{|c|c|c|c|c|c|c|c|c|}
\hline \multirow[b]{2}{*}{ Isolate ${ }^{\mathrm{x}}$} & \multicolumn{4}{|c|}{ Growth rate (mm/day) } & \multicolumn{2}{|c|}{ Fungicide sensitivity ${ }^{\mathrm{y}}$} & \multicolumn{2}{|c|}{ PCR amplification products with primers } \\
\hline & $20^{\circ} \mathrm{C}$ & $25^{\circ} \mathrm{C}$ & $30^{\circ} \mathrm{C}$ & $35^{\circ} \mathrm{C}$ & Benomyl & Captan & CaInt-2 & CgInt \\
\hline EEB 99 & 5.9 & 6.7 & 6.0 & 0.2 & - & + & + & - \\
\hline EEB 100 & 4.6 & 5.4 & 3.4 & $\ldots$ & - & + & + & - \\
\hline EEB 101 & 4.6 & 5.3 & 3.3 & $\ldots$ & - & + & + & - \\
\hline EEB 1995 & 4.8 & 5.6 & 5.1 & $\ldots$ & - & + & + & - \\
\hline EEB 1997 & 4.6 & 5.5 & 3.9 & $\ldots$ & - & + & + & - \\
\hline JEA 92-5 & 7.3 & 8.1 & 7.2 & $\ldots$ & - & + & + & - \\
\hline JEA 92-6 & 7.0 & 8.5 & 7.3 & $\ldots$ & - & + & + & - \\
\hline JEA 92-8 & 6.5 & 7.5 & 7.3 & 0.6 & - & + & + & - \\
\hline JEA 92-16 & 7.4 & 8.5 & 8.1 & $\ldots$ & - & + & + & - \\
\hline JEA 92-18 & 6.7 & 7.6 & 7.0 & 2.1 & - & + & + & - \\
\hline JEA 95-1 & 7.9 & 8.1 & 7.8 & $\ldots$ & - & + & + & - \\
\hline JEA 95-2 & 7.6 & 8.0 & 7.8 & $\ldots$ & - & + & + & - \\
\hline JEA 95-3 & 4.3 & 5.3 & 5.1 & $\ldots$ & - & + & + & - \\
\hline JEA 95-4 & 7.3 & 7.8 & 7.1 & $\ldots$ & - & + & + & - \\
\hline JEA 96-1 & 6.0 & 6.4 & 5.6 & $\ldots$ & - & + & + & - \\
\hline JEA 96-2 & 7.8 & 8.3 & 7.5 & $\ldots$ & - & + & + & - \\
\hline JEA 96-7 & 5.7 & 6.2 & 5.6 & $\ldots$ & - & + & + & - \\
\hline JEA 96-8 & 7.7 & 8.8 & 8.2 & $\ldots$ & - & + & + & - \\
\hline JEA 96-14 & 7.5 & 9.9 & 8.7 & $\ldots$ & - & + & + & - \\
\hline JEA 96-15 & 4.9 & 6.4 & 6.0 & $\ldots$ & - & + & + & - \\
\hline BLT 95-3 & 7.7 & 8.8 & 7.3 & $\ldots$ & - & + & + & - \\
\hline BLT 95-4 & 7.7 & 8.5 & 7.2 & $\ldots$ & - & + & + & - \\
\hline BLT 95-5 & 5.8 & 6.9 & 5.7 & $\ldots$ & - & + & + & - \\
\hline BLT 95-6 & 5.9 & 6.3 & 5.7 & $\ldots$ & - & + & + & - \\
\hline BLT 95-7 & 5.9 & 6.5 & 5.3 & $\ldots$ & - & + & + & - \\
\hline BLT 95-8 & 7.9 & 8.4 & 7.7 & $\ldots$ & - & + & + & - \\
\hline BLT 95-9 & 4.4 & 4.9 & 2.9 & $\ldots$ & - & + & + & - \\
\hline BLT 95-10 & 7.7 & 8.3 & 7.2 & $\ldots$ & - & + & + & - \\
\hline BLT 95-11 & 7.9 & 8.9 & 8.3 & $\ldots$ & - & + & + & - \\
\hline BLT 95-17 & 5.9 & 6.8 & 5.7 & $\ldots$ & - & + & + & - \\
\hline BLT 95-18 & 8.1 & 8.8 & 8.9 & $\ldots$ & - & + & + & - \\
\hline BLT 95-19 & 9.1 & 9.2 & 7.8 & $\ldots$ & - & + & + & - \\
\hline ВТМ 95-4 & 6.6 & 7.8 & 5.9 & 3.1 & - & + & + & - \\
\hline ВТМ 95-5 & 7.4 & 7.9 & 7.4 & $\ldots$ & - & + & + & - \\
\hline ВТМ 95-6 & 7.1 & 8.7 & 8.7 & $\ldots$ & - & + & + & - \\
\hline ВТМ 95-7 & 7.7 & 8.4 & 7.2 & $\ldots$ & - & + & + & - \\
\hline ВТМ 95-8 & 7.2 & 8.5 & 7.1 & $\ldots$ & - & + & + & - \\
\hline EIZ 719 & 8.2 & 9.5 & 8.2 & 0.0 & - & + & + & - \\
\hline EIZ 720 & 8.4 & 9.6 & 5.6 & $\ldots$ & - & + & + & - \\
\hline EIZ 721 & 5.6 & 9.1 & 8.1 & $\ldots$ & - & + & + & - \\
\hline EIZ 722 & 8.6 & 9.4 & 7.7 & $\ldots$ & - & + & + & - \\
\hline EIZ 723 & 7.8 & 8.6 & 5.9 & $\ldots$ & - & + & + & - \\
\hline JMO 94-22 & $\ldots$ & 8.5 & 12.1 & 5.9 & + & + & - & + \\
\hline RJH 96-1 & $\ldots$ & 6.2 & 6.4 & 0.0 & + & + & - & + \\
\hline RJH 96-2 & $\ldots$ & 5.7 & 5.6 & 0.0 & + & + & - & + \\
\hline RJH 96-3 & $\ldots$ & 12.6 & 16.6 & 5.0 & + & + & - & + \\
\hline RJH 96-4 & $\ldots$ & 8.7 & 11.9 & 4.9 & + & + & - & + \\
\hline RJH 96-6 & $\ldots$ & 12.6 & 14.8 & 2.8 & + & + & - & + \\
\hline RJH 96-7 & $\ldots$ & 12.6 & 16.0 & 6.5 & + & + & - & + \\
\hline RJH 96-9 & $\ldots$ & 11.4 & 14.2 & 5.1 & + & + & - & + \\
\hline RJH 96-10 & $\ldots$ & 12.6 & 15.6 & 4.5 & + & + & - & + \\
\hline
\end{tabular}

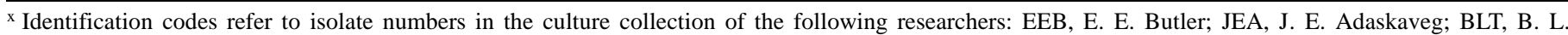
Teviotdale; BTM, B. T. Manji; RJH, R. J. Hartin; and EIZ, E. I. Zehr.

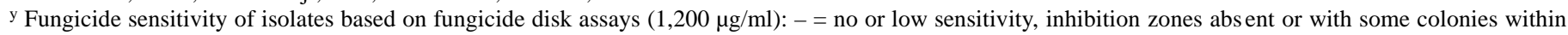
inhibition zone; and $+=$ sensitive, no colonies within inhibition zones.

${ }^{\mathrm{z}}$ PCR amplification with CaInt-2 or CgInt and ITS 4 ribosomal DNA primers with genomic DNA of isolates: $+=$ DNA product present; $-=$ DNA product absent. 
was commonly orangish and occasionally reddish (pinkish) to gray. Strawberry isolates from California and peach and apple isolates from South Carolina were similar in cultural morphology. Cultures obtained from citrus and papaya had grayish aerial mycelium with bright orange spore masses. The reverse of cultures was mostly grayish-white to greenish.

For each of the isolates evaluated, conidial morphology was compared when grown on PDA, PSA, or almond fruit (Fig. 1). On PDA, conidia ranged from short (almond isolate) or long (citrus and papaya isolates) elliptical cells with rounded ends to elliptical cells with acute ends (strawberry isolates). On PSA and almond fruit, conidia of the almond isolates had more acute ends, similar to conidia of the strawberry isolates (Fig. 1) and peach and apple isolates from South Carolina. Cell ends of conidia of the citrus and papaya isolates were rounded on PSA and almond fruit (Fig. 1). The independent variables, isolate, medium, and their interaction, had significant effects on length $(P<0.10)$, width $(P<$ $0.0001)$, and length/width $(\mathrm{L} / \mathrm{W})$ ratio $(P<0.0001)$ of conidia of each isolate evaluated. No differences were observed between experiments $(P>0.05)$. In comparisons of $\mathrm{L} / \mathrm{W}$ ratio, all isolates were significantly different when grown on PDA (Table 2). On PSA, L/W ratio of conidia from the citrus (JMO 94-22) and papaya (RJH 96-4) isolates were significantly different $(P<0.05)$ from all other isolates (Table 2 ). $\mathrm{L} / \mathrm{W}$ ratios of the latter two isolates were also different from each other. On almond fruit, L/W ratios of conidia from almond and citrus isolates were not significantly different $(P>0.05)$, whereas those of strawberry, peach (from CA), and papaya isolates were significantly different $(P<$ 0.05) from the other isolates and from each other (Table 2).

Temperature relationships. Citrus and papaya isolates had optimal growth rates at $30^{\circ} \mathrm{C}$ (Fig. $2 \mathrm{~A}$, Table 3 ); whereas almond, peach, and strawberry isolates had similar temperature responses with optimal growth rates of $25^{\circ} \mathrm{C}$ (Fig. 2B, Table 3). All isolates grew at 10 and $35^{\circ} \mathrm{C}$ (approximately $5 \mathrm{~mm} /$ day), but did not grow at $40^{\circ} \mathrm{C}$ after 5 days (Fig. $2 \mathrm{~A}$ and $\mathrm{B}$ ).

Sensitivity of Colletotrichum isolates to benomyl and captan. All isolates evaluated were sensitive to captan (Fig. 3A, Table 4) and showed a variable response to benomyl (Fig. 3B, Table 4). Comparing fungicides for all concentrations and isolates evaluated, inhibition zones caused by captan and benomyl were significantly different $(P<0.001)$ and averaged 3.9 and $6.1 \mathrm{~mm}$, respectively. For each fungicide, the general linear model was significant
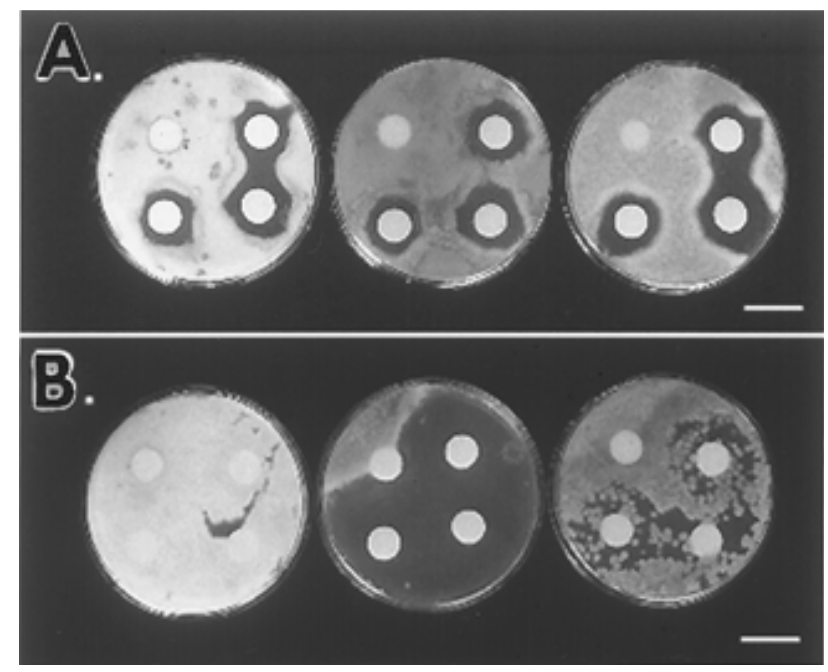

Fig. 3. Fungicide disk assay showing inhibition zones of three Colletotrichum isolates (petri dishes; left to right): strawberry (isolate EEB 101), citrus (isolate JMO 94-22), and almond (isolate JEA 92-8) for A, captan; or B, benomyl. Disk concentrations in each plate were 0, 300 (top disks; left to right), 600, and $1,200 \mu \mathrm{g} / \mathrm{ml}$ (bottom disks, left to right) of either captan or benomyl. Note the numerous colonies within inhibition zones of the almond isolate to benomyl. Bars $=21 \mathrm{~mm}$. with a high level of confidence $(P<0.001)$, and the independent variables concentration, original isolation host, and their interaction had significant $(P<0.001)$ effects on the dependent variable inhibition zone. For captan, inhibition zones increased with fungicide oncentration for isolates grouped by original isolation host (Table 4). Although significant differences $(P<0.02)$ in size of the inhibition zones caused by high rates of captan were observed among the grouped isolates, the inhibition zones were similar in size (Table 4). In contrast, inhibition zones caused by benomyl were significantly different $(P<0.01)$ for isolates grouped by original isolation host (Table 4). Several groups were formed depending on the fungicide concentration. In general, citrus and papaya isolates of $C$. gloeosporioides were highly sensitive to benomyl, with inhibition zones ranging from 14.7 to $19.0 \mathrm{~mm}$ in radius for all concentrations evaluated. Almond and peach isolates of C. acutatum, however, were less sensitive, with mean inhibition zones ranging from 1.4 to $8.3 \mathrm{~mm}$ in radius. With these isolates, numerous colonies formed within the inhibition zones (Fig. 3). The strawberry

TABLE 4. Toxicity of benomyl or captan $(300,600$, or $1,200 \mu \mathrm{g} / \mathrm{ml})$ in agar disk assays to selected isolates of Colletotrichum spp. identified by their original host ${ }^{\mathrm{y}}$

\begin{tabular}{|c|c|c|c|c|c|}
\hline \multirow[b]{2}{*}{ Fungicide } & \multirow[b]{2}{*}{ Original host } & \multirow[b]{2}{*}{ Isolates } & \multicolumn{3}{|c|}{$\begin{array}{l}\text { Mean radius of inhibition zone }(\mathrm{mm}) \\
\text { per fungicide concentration }(\mu \mathrm{g} / \mathrm{ml})^{\mathrm{z}}\end{array}$} \\
\hline & & & 300 & 600 & 1,200 \\
\hline \multirow[t]{8}{*}{ Captan } & Citrus & JMO 94-22 & $4.7 \mathrm{a}$ & $4.8 \mathrm{ab}$ & $6.6 \mathrm{ab}$ \\
\hline & Papaya & RJH 96-4 & $3.4 \mathrm{a}$ & $5.9 \mathrm{a}$ & $8.6 \mathrm{a}$ \\
\hline & & RJH 96-7 & & & \\
\hline & Almond & JEA 92-8 & $4.5 \mathrm{a}$ & $5.0 \mathrm{ab}$ & $6.7 \mathrm{ab}$ \\
\hline & & JEA 92-18 & & & \\
\hline & & JEA 95-4 & & & \\
\hline & Peach & ВТМ 95-1 & $3.4 \mathrm{a}$ & $6.0 \mathrm{a}$ & $6.7 \mathrm{ab}$ \\
\hline & Strawberry & EEB 99 & $3.0 \mathrm{~b}$ & $3.8 \mathrm{~b}$ & $5.1 \mathrm{~b}$ \\
\hline \multirow[t]{8}{*}{ Benomyl } & Citrus & JMO 94-22 & $18.5 \mathrm{a}$ & $18.5 \mathrm{a}$ & $19.0 \mathrm{a}$ \\
\hline & Papaya & RJH 96-4 & $14.7 \mathrm{~b}$ & $14.7 \mathrm{a}$ & $15.7 \mathrm{a}$ \\
\hline & & RJH 96-7 & & & \\
\hline & Almond & JEA 92-8 & $2.5 \mathrm{c}$ & $3.0 \mathrm{bc}$ & $3.3 \mathrm{c}$ \\
\hline & & JEA 92-18 & & & \\
\hline & & JEA 95-4 & & & \\
\hline & Peach & ВТМ 95-1 & $1.4 \mathrm{c}$ & $4.1 \mathrm{~b}$ & $8.3 \mathrm{~b}$ \\
\hline & Strawberry & EEB 99 & $0.0 \mathrm{c}$ & $0.0 \mathrm{c}$ & $0.2 \mathrm{c}$ \\
\hline
\end{tabular}

y Potato dextrose agar plates were simultaneously inoculated with each isolate using $100 \mu \mathrm{l}$ of a conidial suspension $(30,000$ conidia $/ \mathrm{ml})$, filter disks saturated in $0,300,600$, or $1,200 \mu \mathrm{g} / \mathrm{ml}$ were placed on the agar surface, and the plates were incubated for 3 days at $25^{\circ} \mathrm{C}$. No inhibition zone occurred at the $0 \mu \mathrm{g} / \mathrm{ml}$ concentration of each fungicide evaluated.

${ }^{\mathrm{z}}$ Mean radius of inhibition zones of six replications from two experiments (three replications/experiment) for the isolates evaluated for each host and fungicide concentration. For each fungicide and concentration, values followed by the same letter were not significantly different using Tukey's studentized range test $(P<0.01)$.

TABLE 5. Effect of inoculation method on disease incidence of almond fruit inoculated with an isolate of Colletotrichum acutatum from almond under laboratory and field conditions

\begin{tabular}{lcc}
\hline & \multicolumn{2}{c}{ Incidence $(\%)$ of fruit infection ${ }^{\mathrm{z}}$} \\
\cline { 2 - 3 } Inoculation methody & Laboratory & Field \\
\hline Check & $0 \mathrm{c}$ & $0 \mathrm{c}$ \\
Nonwounded, spray & $40.0 \mathrm{~b}$ & $7.8 \mathrm{~b}$ \\
Wounded, drop & $100.0 \mathrm{a}$ & $67.3 \mathrm{a}$ \\
\hline
\end{tabular}

${ }^{y}$ Fruit were inoculated with JEA $92-6$ or $92-16$ (30,000 conidia/ml). For both field experiments, daily average temperature and relative humidity ranged from 57 to $75^{\circ} \mathrm{C}$ and 37 to $66 \%$, respectively.

${ }^{\mathrm{z}}$ Evaluations were made after 10 days. For laboratory studies, values are the average of eight (five fruit/replication) replications from two experiments. For field studies, values are the average of eight replications (15 to 20 fruit/replication) from two experiments. Values within each column followed by the same letter were not significantly different based on Duncan's multiple range test for mean separation $(P<0.05)$. 
isolate of $C$. acutatum was least sensitive, with a mean inhibition zone of $0.2 \mathrm{~mm}$ at only the $1,200 \mu \mathrm{g} / \mathrm{ml}$ of concentration of benomyl. No differences were observed between experiments $(P>0.10)$.

Pathogenicity of Colletotrichum isolates on almond and peach. In both laboratory and field studies using almond fruit, wounded and nonwounded inoculations using two almond isolates resulted in fruit infections (Table 5). Fruit symptoms from both inoculations were similar to those observed naturally in the field, and reisolations yielded the Colletotrichum isolates. Significant differences $(P<0.05)$ were observed between inoculation methods (Table 5). In both laboratory and field studies, wounded drop inoculations produced a higher incidence of disease than did nonwounded spray inoculations. In laboratory wound-inoculation studies, all isolates evaluated were pathogenic to almond and peach fruit. No difference $(P>0.05)$ in disease incidence caused by the isolates evaluated was observed.

Molecular characterization of Colletotrichum isolates. Four species-specific target primers from ITS 1 and primer ITS 4 regions were used in PCR to amplify rDNA from genomic DNA of the isolates used in this study (Table 1). Both CaInt primers specific to $C$. acutatum produced PCR products of approximately $0.5 \mathrm{~kb}$ (as indicated by the $\lambda$-Hind III marker) with strawberry, almond, apple, and peach isolates (Figs. 4A and $\mathrm{C}$ and 5A). No PCR products were produced with either CaInt (-1 or -2$)$ primer for the citrus and papaya isolates of $C$. gloeosporioides (Table 3). PCR products were produced with the CgInt primer for the citrus and papaya isolates of C. gloeosporioides (Figs. 4B and 5B), however, the CfInt primer only produced products with the papaya isolates (Fig. 4D). Neither CgInt nor CfInt primers produced PCR products with $C$. acutatum isolates from strawberry, almond, and peach (Figs. 4B and D and 5B). No PCR products were produced with water checks in any amplifications. A summary of DNA amplification products for primers CaInt- 1 or CgInt and ITS 4 for all isolates used in this study is shown in Table 3.

\section{DISCUSSION}

Almond and peach isolates of $C$. acutatum were demonstrated to be pathogenic on wounded and nonwounded fruit and were reisolated, fulfilling Koch's postulates. An anthracnose disease outbreak of fruit on almond and isolated occurrences on peach in California were caused by these isolates. Almond and peach isolates

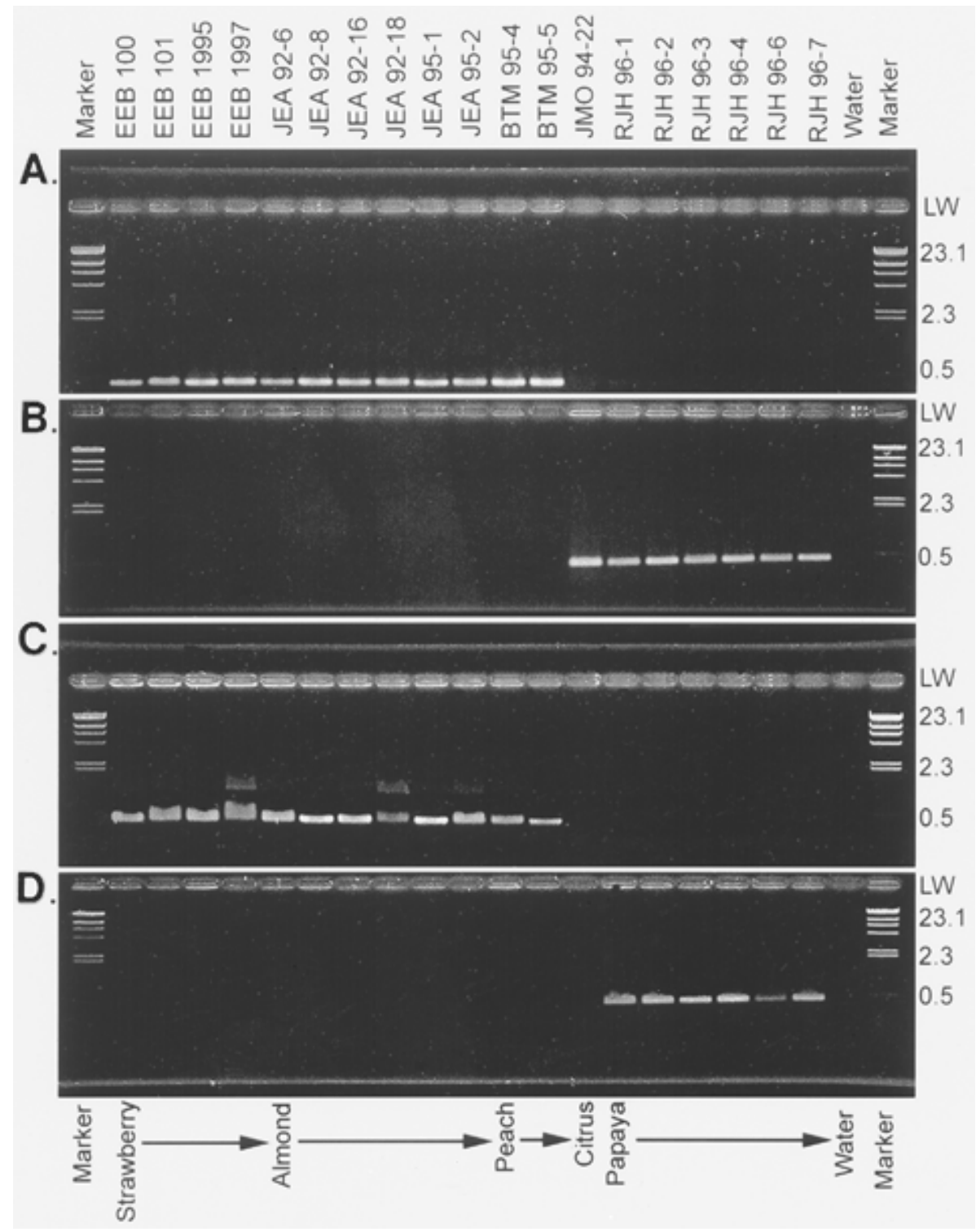

Fig. 4. Amplification products and markers in agarose gels stained with ethidium bromide for ITS ribosomal DNA primers A, CaInt-2; B, CgInt; C, CaInt-1; and D, CfInt and photographed using transmitted UV light. Isolates of Colletotrichum species are indicated across the top, and original isolation hosts across the bottom. JMO and RJH isolates are $C$. gloeosporioides and all others are $C$. acutatum. Marker used was $\lambda$-Hind III, and molecular weights are shown on the right for each gel. $\mathrm{LW}=$ loading well. 
from California were compared with strawberry, peach, and apple isolates of C. acutatum and citrus and papaya isolates of C. gloeosporioides using classical criteria such as conidial morphology, temperature relationships, and fungicide sensitivity, as well as by PCR amplification techniques based on published rDNA sequence information of selected Colletotrichum species. Based on these comparative studies, isolates of Colletotrichum from almond and peach in California were characterized as most similar to $C$. $a c u$ tatum, as in a preliminary study (2), rather than the previously reported C. gloeosporioides $(19,20)$. In our study, almond and peach isolates from California produced a PCR amplification product of approximately the same molecular weight as that from known $C$. acutatum isolates from strawberry, apple, and peach (from SC). Temperature relationships and benomyl sensitivity were less definitive, but also indicated similarity of the almond and peach isolates to strawberry, apple, and peach (from SC) isolates of C. acutatum. Using these criteria, all of the almond and peach isolates from California were distinct from the $C$. gloeosporioides isolates from papaya and citrus. Freeman et al. (9), using arbitrarily primed PCR, also indicated that almond isolates from California were distinct from almond isolates from Israel. On peach and other fruit tree crops, Bernstein et al. (4) indicated that two species of $\mathrm{Col}$ letotrichum, C. gloeosporioides and C. acutatum, occur in the southeast United States. Thus, this is the first report of $C$. acutatum on almond and the second report of this species on peach. Both reports are new for California.

In a previous study of isolates of Colletotrichum (17), the CgInt and ITS 4 primers produced PCR products with DNA from $C$. gloeosporioides, C. fragariae, and $C$. kahawe, but not with DNA from $C$. acutatum or several other species of Colletotrichum. In our study, the CgInt and ITS 4 primers only produced PCR products with citrus and papaya isolates representing C. gloeosporioides. Interestingly, the CfInt and ITS primers only produced PCR products with papaya isolates and not with our citrus isolate. The CfInt primer differed from the CgInt primer in three base pairs

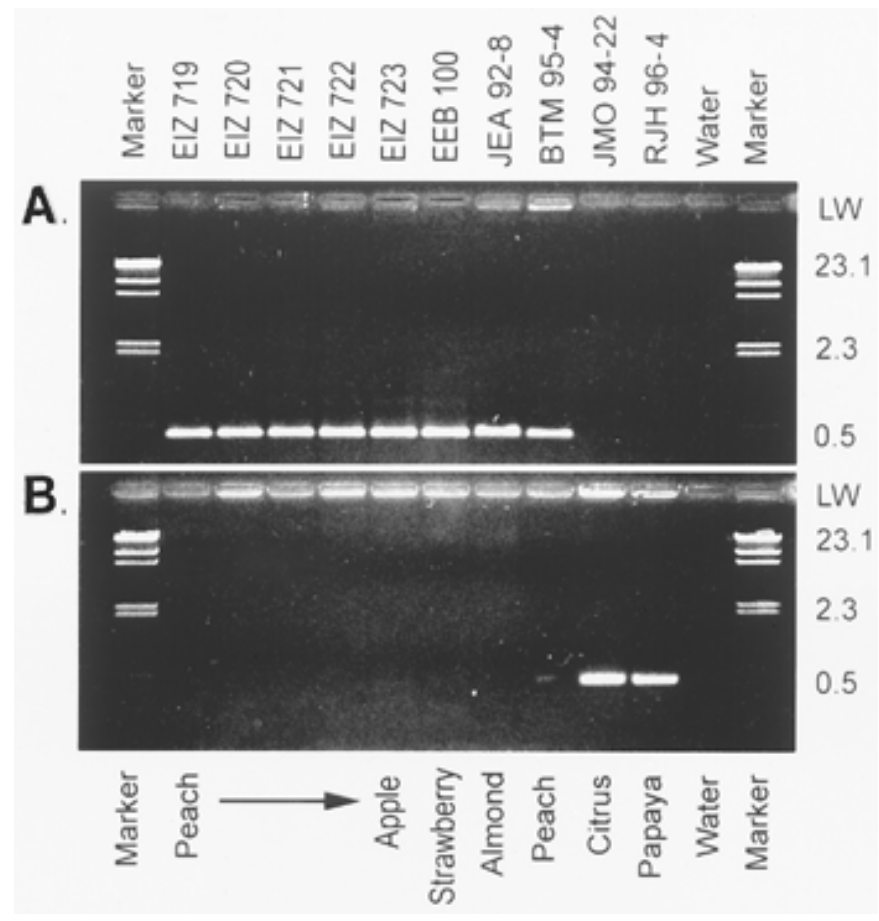

Fig. 5. Amplification products and markers in agarose gels stained with ethidium bromide for ITS ribosomal DNA primers A, CaInt-2; and B, CgInt and photographed using transmitted UV light. Isolates of Colletotrichum species are indicated across the top, and original isolation hosts across the bottom. JMO and RJH isolates are $C$. gloeosporioides and all others are $C$. acutatum. Marker used was $\lambda$-Hind III, and molecular weights are shown on the right for each gel. LW = loading well. (bp) and, thus, differences among isolates of C. gloeosporioides could be detected with the use of these primers. Sreenivasaprasad et al. (23,24), using restriction fragment length polymorphism analyses of ribosomal and mitochondrial DNA and sequence analyses, however, suggested that, because of the molecular similarity of $C$. gloeosporioides, $C$. fragariae, and $C$. kahawe, they should not be considered separate species.

Our use of a 23- and a 22-bp sequence from a variable region of ITS 1 was specific to $C$. acutatum isolates in North America. In contrast, Mills et al. (17) used a 17-bp ITS 1 primer that produced DNA products with isolates of $C$. acutatum, but also with one isolate each of C. gloeosporioides and C. fragariae. Recently, Sreenivasaprasad et al. (25) also developed a C. acutatum-specific, 17-bp primer from the variable ITS 1 region of $C$. acutatum that also amplified DNA extracted from infested strawberry tissue. These specific primers probably can be used for rapid and accurate identification of almond tissues infected by $C$. acutatum in California.

Growth rates of almond and peach isolates from California and isolates of C. acutatum from strawberry, apple, and peach (from SC) were generally slower at all temperatures compared with isolates of $C$. gloeosporioides. Maximum growth rates for $C$. acutatum isolates were between 5 and $10 \mathrm{~mm} /$ day after 5 days at $25^{\circ} \mathrm{C}$, whereas isolates of $C$. gloeosporioides had maximum growth rates between 10 and $15 \mathrm{~mm} /$ day after 5 days at $30^{\circ} \mathrm{C}$. These results are consistent with other studies that used temperature relationships to distinguish $C$. acutatum from $C$. gloeosporioides on other hosts $(4,14,21,26)$.

The fungicide sensitivity assays using benomyl indicated differences between $C$. acutatum and $C$. gloeosporioides. Strawberry isolates showed no inhibition zones at the 300 and $600 \mu \mathrm{g} / \mathrm{ml}$ of concentrations of benomyl evaluated. Almond and peach isolates showed some sensitivity, with an average inhibition zone of 1.4 to $8.3 \mathrm{~mm}$ to the concentrations of benomyl (300 to $1,200 \mu \mathrm{g} / \mathrm{ml}$ ) evaluated. Numerous small colonies, however, also developed within the inhibition zone, suggesting a possible selection of benomylresistant subpopulations among conidial suspensions of each isolate. In contrast, all concentrations of benomyl produced large distinct inhibition zones to citrus and papaya isolates. Bernstein and Miller (3) and Bernstein et al. (4) also indicated the sensitivity of C. gloeosporioides and the insensitivity of $C$. acutatum to benomyl. Benomyl has been used commonly in both strawberry fields and almond/peach orchards in California for management of gray mold (Botrytis cinerea) and brown rot (Monilinia spp.), respectively. We can speculate that the recent outbreak of anthracnose in almonds and peaches is from endemic populations of $C$. acutatum that were previously exposed to benomyl or that the species is inherently resistant to benomyl and was introduced into California. More importantly, these results indicate that benomyl may not provide disease control in the field, whereas captan should provide adequate management against Colletotrichum isolates from almonds and peach in California.

The limited number of morphological and cultural characters of Colletotrichum species, the lack of standardization of cultural conditions among different researchers around the world, and the inherent plasticity of individual isolates of these fungi have led to confusion and uncertainty in the characterization of many species of Colletotrichum (26). Additionally, many species of Colletotrichum have been recorded on a large number of hosts and, thus, species concepts within the genus are broad and have been based on morphology, presence of a teleomorph, and host symptoms. Identification based only on these criteria often lacked consistency and precision (26). We confirmed these inherent taxonomic problems with the species of Colletotrichum found on almonds and peach in California using classical morphological criteria. The range of cultural characteristics overlapped somewhat. Conidial morphology was variable depending on the medium or substrate used. Similarly, Gunnell and Gubler (14) found that a strawberry 
leaf medium allowed for isolates of C. acutatum, C. gloeosporioides, and $C$. fragariae to be distinguished morphologically. In our study, L/W ratios were not as useful for distinguishing the $\mathrm{Col}$ letotrichum species evaluated. Lack of standardization of cultural conditions to obtain conidial morphology data for species identification has lead to greater taxonomic confusion (26).

Freeman et al. (9), using PCR analyses, identified 57 almond isolates from nine different geographical regions within Israel as $C$. gloeosporioides. Using four distinct primers, almond isolates from California were different from those from Israel, but they were not identified to species (9). Our collection of California isolates from almond are similar to and can be characterized as $C$. acutatum, although slight differences in conidial morphology and benomyl sensitivity were observed. Additional molecular comparisons are needed to determine if almond and peach isolates from California are distinct populations of $C$. acutatum.

In the current study, all of the Colletotrichum isolates evaluated were able to infect wounded almond fruit regardless of the original host. Both avocado and almond isolates of $C$. gloeosporioides from Israel were able to infect nonwounded almond fruit, with relatively little difference in severity; however, almond isolates caused only small infections on avocado (9). Bernstein et al. (4) also indicated that $C$. acutatum and $C$. gloeosporioides occur on apple, peach, and pecan. Because these species have a broad host range and they occur on strawberry (14), other species of Colletotrichum may occur on almond in California. Larger samples of populations of Colletotrichum from almond and peach in California are needed to determine if $C$. gloeosporioides or other species occur on Prunus spp. in addition to $C$. acutatum. Currently, on a worldwide basis, almond anthracnose may be caused by populations of either C. gloeosporioides (e.g., Israel), as previously reported, or by $C$. acutatum (e.g., California), as indicated in this study.

\section{ACKNOWLEDGMENTS}

We thank the Almond Board of California for financial support. We also thank C. Smart and B. Kirkpatrick for their assistance in conducting preliminary polymerase chain reaction experiments; E. E. Butler, D. Kim, E. Zehr, and B. Teviotdale for help in obtaining or culturing Colletotrichum isolates; B. Manji and D. Thompson for collecting almond and peach isolates; P. A. Mauk for reviewing this manuscript; and the late J. M. Ogawa for his encouragement and support for conducting these studies.

\section{LITERATURE CITED}

1. Adaskaveg, J. E., and Hartin, R. J. 1996. Outbreak of almond anthracnose in California caused by the previously unreported Colletotrichum acutatum. (Abstr.) Phytopathology 86:S22.

2. Adaskaveg, J. E., and Ogawa, J. M. 1992. Control of almond diseases. Pages 19-24 in: Proc. Annu. Almond Res. Conf., 20th. Almond Board of California, Modesto, CA.

3. Bernstein, B., and Miller, R. W. 1995. Anthracnose. Pages 18-19 in: Compendium of Stone Fruit Diseases. J. M. Ogawa, E. I. Zehr, G. W. Bird, D. F. Ritchie, K. Uriu, and J. K. Uyemoto, eds. The American Phytopathological Society, St. Paul, MN.

4. Bernstein, B., Zehr, E. I., Dean, R. A., and Shabi, E. 1995. Characteristics of Colletotrichum from peach, apple, pecan, and other hosts. Plant Dis. 79:478-482.

5. Czarnecki, H. L. 1916. A Gloeosporium disease of the almond probably new to America. (Abstr.) Phytopathology 6:310.

6. Dippenaar, B. J. 1931. Anthracnose disease of almonds. Farm. S Africa 6:133-134.

7. Dyko, B. J., and Mordue, J. E. M. 1979. Colletotrichum acutatum. CMI
(Commonw. Mycol. Inst.) Descr. Pathog. Fungi Bact. No. 630.

8. Farr, D. F., Bills, G. F., Chamauris, G. P., and Rossman, A. Y. 1989. Fungi on Plants and Plant Products in the United States. The American Phytopathological Society, St. Paul, MN.

9. Freeman, S., Katan, T., and Shabi, E. 1996. Characterization of Colletotrichum gloeosporioides isolates from avocado and almond fruit with molecular and pathogenicity tests. Appl. Environ. Microbiol. 62:1014-1020.

10. Freeman, S., Pham, M., and Rodriguez, R. J. 1993. Molecular genotyping of Colletotrichum species based on arbitrarily primed PCR, A+T-rich DNA and nuclear DNA analyses. Exp. Mycol. 17:309-322.

11. Freeman, S., and Rodriguez, R. J. 1993. Molecular genotyping of Colletotrichum species responsible for anthracnose of strawberry by arbitrarily primed PCR. Mycol. Res. 99:501-504.

12. French, A. M. 1989. California Plant Disease Host Index. California Department of Food and Agriculture, Sacramento, CA.

13. Grosclaude, C. 1972. L'anthracnose de l'amandier en France. C. R. Acad. Agric. Fr. 58:1392-1395.

14. Gunnell, P. S., and Gubler, W. D. 1992. Taxonomy and morphology of Colletotrichum species pathogenic to strawberry. Mycologia 84:157-165.

15. Hodson, A., Mills, P. R., and Brown, A. E. 1993. Ribosomal and mitochondrial DNA polymorphisms in Colletotrichum gloeosporioides isolated from tropical fruits. Mycol. Res. 97:329-335.

16. Mills, P. R., Hodson, A., and Brown, A. E. 1992. Molecular differentiation of Colletotrichum gloeosporioides isolates infecting tropical crops. Pages 269-288 in: Colletotrichum-Biology, Pathology, and Control. J. A. Bailey and M. J. Jeger, eds. CAB International, Wallingford, United Kingdom.

17. Mills, P. R., Sreenivasaprasad, S., and Brown, A. E. 1994. Detection of the anthracnose pathogen Colletotrichum. Pages 183-189 in: Modern Assays for Plant Pathogenic Fungi: Identification, Detection and Quantification. A. Schots, F. M. Dewey, and R. Oliver, eds. CAB International, Oxford.

18. Mordue, J. E. M. 1971. Glomerella cingulata. CMI (Commonw. Mycol. Inst.) Descr. Pathog. Fungi Bact. No. 315.

19. Ogawa, J. M., and English, H. 1991. Diseases of Temperate Zone Tree Fruit and Nut Crops. Publication 3345. University of California, Division of Agriculture and Natural Resources, Oakland.

20. Shabi, E., and Katan, T. 1983. Occurrence and control of anthracnose of almond in Israel. Plant Dis. 67:1364-1366.

21. Simmonds, J. H. 1965. A study of the species Colletotrichum causing ripe fruit rots in Queensland. Queensl. J. Agric. Anim. Sci. 22:437-459.

22. Smith, R. E. 1941. Diseases of fruits and nuts. Univ. Calif. Agric. Exp. Stn. Circ. 120.

23. Sreenivasaprasad, S., Brown, A. E., and Mills, P. R. 1993. Coffee berry disease pathogen in Africa: Genetic structure and relationship to the group species Colletotrichum gloeosporioides. Mycol. Res. 97:995-1000.

24. Sreenivasaprasad, S., Brown, A. E., and Mills, P. R. 1993. DNA sequence variation and interrelationships among Colletotrichum species causing strawberry anthracnose. Physiol. Mol. Plant Pathol. 41:265-281.

25. Sreenivasaprasad, S., Sharada, K., Brown, A. E., and Mills, P. R. 1996. PCR-based detection of Colletotrichum acutatum on strawberry. Plant Pathol. 45:650-655.

26. Sutton, B. C. 1992. The genus Glomerella and its anamorph Colletotrichum. Pages 1-26 in: Colletotrichum-Biology, Pathology, and Control. J. A. Bailey and M. J. Jeger, eds. CAB International, Wallingford, United Kingdom.

27. Taylor, R. H., and Philp, G. L. 1925. The almond in California. Univ. Calif. Agric. Exp. Stn. Circ. 284.

28. Tuite, J. 1960. Plant Pathological Methods-Fungi and Bacteria. Burgess Publishing Company, Minneapolis, MN.

29. von Arx, J. A. 1957. Die arten der Gattung Colletotrichum Cda. Phytopathol. Z. 29:413-468.

30. Waller, J. M. 1992. Colletotrichum diseases of perennial and other cash crops. Pages 167-185 in: Colletotrichum-Biology, Pathology, and Control. J. A. Bailey and M. J. Jeger, eds. CAB International, Wallingford, United Kingdom.

31. White, T. J., Bruns, T., Lee, S., and Taylor, J. 1990. Amplification and direct sequencing of fungal ribosomal RNA genes for phylogenetics. Pages 315-322 in: PCR Protocols, A Guide to Methods and Applications. M. A. Innis, D. H. Gefland, J. J. Sninsky, and T. J. White, eds. Academic Press, San Diego, CA. 